\title{
Patiëntenvoorlichting
}

\section{PV 43. Folliculaire cyste}

Rond een nog in het kaakbot gelegen tand of kies kan zich in het om de tand of kies gelegen tandzakje (=follikel) door een onbekende oorzaak vocht ophopen. Dit wordt een folliculaire cyste genoemd. Een dergelijke zich in het kaakbot uitbreidende cyste kan soms grote afmetingen aannemen. Folliculaire cysten komen vrijwel uitsluitend voor bij de blijvende tanden en kiezen, in het bijzonder bij de verstandskiezen in de onderkaak en soms ook de hoektanden in de bovenkaak. Bij melktanden of melkkiezen komt zelden een folliculaire cyste tot on twikkeling.

De doorbraak van de bijbehorende tand of kies wordt door een folliculaire cyste belemmerd. Voor het overige veroorzaken folliculaire cysten meestal geen klachten. Ze worden meestal bij toeval op een röntgenfoto ontdekt. In principe zal een folliculaire de cyste worden verwijderd. Wanneer het om een verstandskies in de bovenkaak gaat, of, een enkele maal de bovenkaak, wordt ook de bijbehorende verstandskies verwijderd. Wanneer het om meer vooraan in de mond gelegen tanden of kiezen gaat, is het vaak mogelijk de bijbehorende tand of kies te sparen en alsnog in de mond te laten doorbreken. Vaak wordt de cyste na verwijdering opgestuurd naar de patholoog ter verificatie van de diagnose. De genezing van de in het kaakbot door de cyste veroorzaakte holte verloopt doorgaans voorspoedig.

\section{Wat kunt u zelf doen?}

Hoewel een folliculaire cyste meestal geen klachten veroorzaakt, is het doorgaans aangewezen de cyste te laten behandelen.
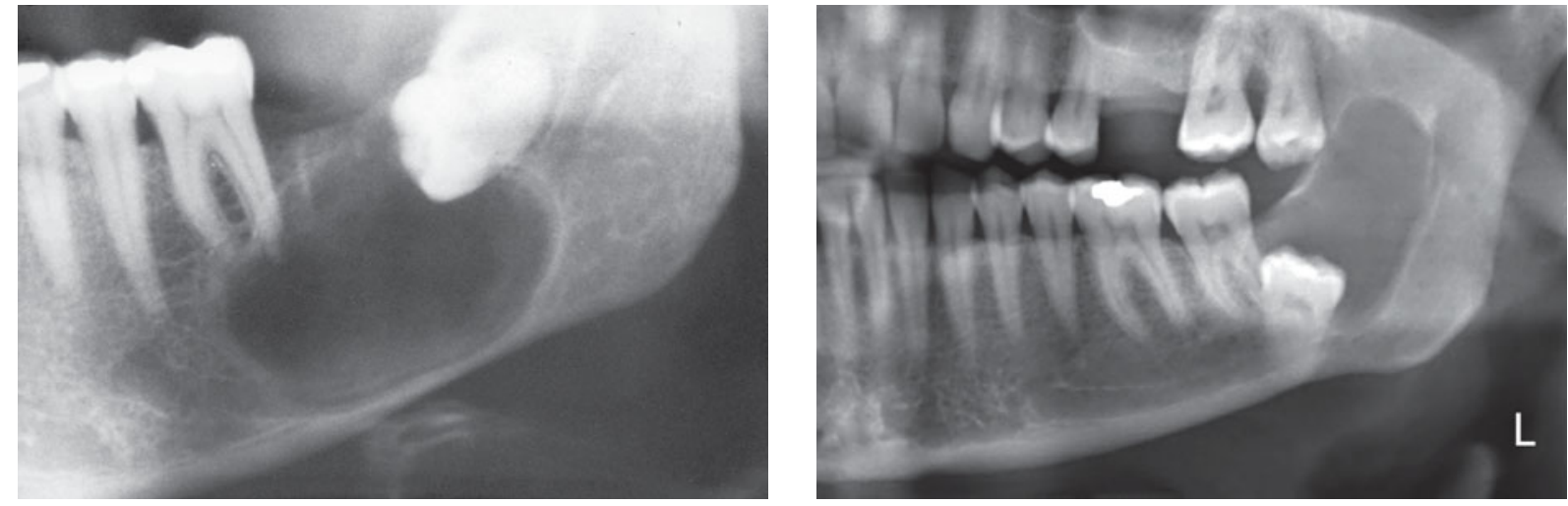